\title{
The Habit Makes the Monk: Clothes/Cloth and Valuation in Joinville's « Vie de saint Louis »
}

\section{Reginald Hyatte}

\section{Q OpenEdition \\ 1 Journals}

\section{Electronic version}

URL: http://journals.openedition.org/studifrancesi/29817

DOI: $10.4000 /$ studifrancesi.29817

ISSN: 2421-5856

\section{Publisher}

Rosenberg \& Sellier

\section{Printed version}

Date of publication: 1 April 2006

Number of pages: 7-16

ISSN: 0039-2944

\section{Electronic reference}

Reginald Hyatte, "The Habit Makes the Monk: Clothes/Cloth and Valuation in Joinville's «Vie de saint Louis "”, Studi Francesi [Online], 148 (XLX | I) | 2006, Online since 30 November 2015, connection on 22 April 2021. URL: http://journals.openedition.org/studifrancesi/29817 ; DOI: https://doi.org/10.4000/ studifrancesi.29817

\section{(c) $(1)(9)$}

Studi Francesi è distribuita con Licenza Creative Commons Attribuzione - Non commerciale - Non opere derivate 4.0 Internazionale. 


\title{
The Habit Makes the Monk: Clothes/Cloth and Valuation in Joinville's «Vie de saint Louis»
}

\author{
«Tant vaut l'homme, tant vaut la cravate. Et, à vrai dire, \\ la cravate, c'est l'homme; c'est elle par qui l'homme se \\ révèle et se manifeste»—Honoré de Balzac'.
}

The narration dealing with clothing and cloth in La vie de saint Louis (13051309) represents Joinville as a fashion maven in the royal courts of his time. As Jacques Monfrin pointed out, Francesco da Barberino (1264-1348), an Italian notary and author, questioned the aged seneschal of Champagne on French court etiquette and conduct; according to Barberino, Joinville's opinion in such matters was valued highly by his king, Philippe IV Le Bel' ${ }^{2}$. Joinville, in the role of arbiter of courtly custom and costume, appears to take seriously his attempts at fashion policing recounted in La vie de saint Louis. The present essay explores the wide-ranging signification of dress and cloth, which has not been studied in depth previously, as they relate to moral, affective, supernatural, and other valuation explicit or implicit there. For the narrator, style is a language with its own grammatical constructions and conventions, a text of outward signs to be read for inner meanings. Further, fabric and dress in his telling throw light especially on him as a subject of his own narrative.

We will note, moreover, several misreadings and misfits in Joinville's accounts dealing with attire and cloth. Misinterpretation or inappropriate association sometimes results in humor-for example, in anecdotes about a knight's offer of warm clothing to a man who risks drowning and the French queen's mistaking bundles of cloth for holy relics. In the latter instance, the queen's laughter at her error echoes the king's when Joinville jokes that he is not of a mind to take, or mistake, him for a relic, that is, bones to be venerated. Joinville never, it appears, makes laughable mistakes with regard to attire. An entertaining dispute in court between him and Robert de Sorbon treats a serious matter - a misfit between dress and social class - and it validates, on the king's authority, both the appropriateness of Joinville's attire and his fitting judgment in the case. Joinville's narration of his reproach (is it fatherly scolding?) of Louis IX's son, Philippe III Le Hardi, for his expensive taste in court costumes points to a mismatch between the paternal model and the son's practice. There the narrator, favoring the father, judges the mismatch to reflect poorly on the saint-king's successors.

(1) Physiologie de la toilette, in Théorie de la démarche et autres textes, $2^{\text {nd }}$ ed., Paris, A. Michel, 1990 («Bibliothèque Albin Michel, 40»), p. 137.

(2) Vie de saint Louis, ed. and translated into modern French by J. Monfrin, Paris, Dunod, 1995 («Classiques Garnier»), pp. XXVI-XXVII. Quotations and section numbers in the Old French text are from this edition. J. Monfrin cites here Barbarino's Latin prose commentaries in his Documenti d'amore. Barbarino was also the author of Reggimento e costumi di donna. 
Let us examine first the main principle of style in male dress that Joinville propounds. He introduces the rule in the mouth of St. Louis in the section designated as his «saintes paroles et bons enseignemens»: «Il disoit que l'en devoit son cors vestir et armer en tele maniere que les preudeshomes de cest siecle ne deissent que il en feist trop ne que les joenes homes ne deissent que il en feist pou» $(\$ 25)$. Joinville repeats this principle in slightly altered form at $\mathbb{} 38$. In the second instance the king's pronouncement, reproduced in direct discourse, appears to be vested with the formalities of a legal or judicial decision; moreover, its authority is not open to challenge.

We might note several particulars here. Firstly, the principle applies to battle dress as well as court costumes. Joinville illustrates much later the living ideal of military attire in the person of Louis IX as he appears on the field at the battle of Mansûra: «Mes onques si bel armé ne vi, car il paroit de sur toute sa gent des les espaules en amon, un heaume doré en son chief, une espee d'Alemaingne en sa main» $(\$ 228)$.

Secondly, St. Louis's first enunciation of the prime directive of male dress assigns the role of judges to preudeshomes, wise men, presumably not youths, and young noblemen, not typically considered to be wise. The idea of a male's attire, in court or on the battlefield, as the object of other males' evaluating gaze would seem consistent with a predominant male homosociality in both areas. Just before repeating the principle at $\$ 38$, however, St. Louis mentions women as evaluators: he tells his son and son-in-law that they should follow Joinville's advice and dress well and cleanly so that their wives will love them all the more. Thus, as a practical consideration, male self-representation through dress relates to the male and the female evaluative gaze, but with regard to different categories of appreciation: approbation on one hand and heteronormative affection or attraction on the other'.

Thirdly, the principle is overstated with regard to authority. At its first appearance, the king articulates it. In repeating it, he cites it on the authority of an unidentified le sage $e^{4}$, and he recommends Joinville's opinion in the matter. In these two instances Joinville cites the authority of Louis IX's pronouncements to authenticate his own evaluations of attire. We should note an important difference between Joinville's two presentations of Louis's lesson on dress. At $\mathbb{} 38$ the king addresses the lesson to his son, the future Philippe III, and son-in-law, Thibaut II, king of Navarre, in Joinville's presence; at $\$ 25$, after Louis IX’s death, Joinville addresses his own lesson, based on the father's principle and dress, to Philippe III. In the latter version, Joinville replaces the absent king-father as an authority figure prescribing right conduct to the son. In this, the narrator's voice equals in authoritative value the father's which it replaces. The narrator assumes this surrogate-father role elsewhere: at $\$ \$ 766-67$ he reproduces in direct discourse the dead king's voice that he heard in a dream, and he communicates the dream-spirit's «true» message, which he interprets, to Louis IX's great-grandson, the future Louis X Le Hutin.

Let us look now at Joinville's practical applications of the authoritative rule. The principle's binary oppositions of youth versus mature preudeshomes and of too much versus too little offer problematical evaluations in the narrative. Among these prob-

(3) As Jacques Le Goff notes, St. Louis wrote recommendations to his daughter Isabelle on modesty and moderation in female attire-Saint Louis, Paris, Gallimard, 1996 («Bibliothèque des Histoires»), p. 430. For his recommendations, see "Vie de saint Louis" par Guillaume de Saint-Patbus, confesseur de la reine Marguerite, ed. H.-FR. DELABORDE, Paris, A. Picard et Fils, 1899 («Collection de Textes pour Servir à l'Étude et à l'Enseignement de l'Histoire, $27 »)$, p. 62.

(4) Often in Old French le sage refers to King Solomon, but the principle cited at $₫ 38$ does not correspond to anything in the Old Testament didactic books attributed to him. Cf. «ni peu ni prou». 
lems is an apparent contradiction in the narrator's judgments regarding male dress. When at Saumur in 1241 the seventeen-year-old Joinville first attended Louis IX's court, he was, it appears, in awe of the magnificent costumes. His description of the noblemen's attire of silk, gold cloth, taffeta, satin, ermine, appliqué, etc. is a veritable fashion plate of the height of court elegance. His conclusion to the fashion page probably corresponds to his overall impression: «Et dient moult de gent que il n'avoient onques veu autant de seurcoz ne d'autres garnemens de drap d'or et de soye a une feste comme il ot la» (\$97). Nevertheless, he notes that the king's cotton hat «moult mal li seoit pour ce que il estoit lors joenne home» (\$94). The unfavorable evaluation might represent the opinion of a youth who judged that the young king had done too little-compare at $\$ 93$ the suitably elegant attire, including a hat of gold fabric, donned by the count of Champagne-king of Navarre, whom Joinville served at table that day ${ }^{5}$. On the other hand, in upbraiding Philippe III at $\$ 25$ because of the costly embroidered coats of arms he favors, Joinville applies in a different manner the principle that Louis IX articulated. He advises Philippe III to have made less expensive stamped coats of arms like those that St. Louis used during his first crusade, and he claims that Philippe could make better use of his money for charitable works than for fancy apparel. The inconsistency between the narrator's evaluations of elegant attire might be explained by the diversity of his points of view in time: sometimes he represents himself as a youth and at others, a senior preudebome. In the account of the king and his court at Saumur, one finds the young Joinville's appreciation of costly and even showy dress. In preaching on fashion to Philippe III, the senior Joinville prefers the mature St. Louis's «not too much» approach.

At any rate, the narrator's practical application of St. Louis's rule in the latter case sets up the dichotomy of money for attire versus money to do God's work. Joinville notes that after returning from his first crusade, Louis IX, because of his religious devotion, rejected rich fabrics and furs in favor of simple, inexpensive attire $(\$ 667)$. That style of dress indicates a change, a conversion of manners consistent with his profound devotion, good works, and exemplary moral conduct then. $\mathrm{He}$ notes, too, that during Philippe III's and Philippe IV's reigns, embroidered coats of arms - and, one may presume, other costly articles of clothing — are in style. The older Joinville's point is not that the old style of the later part of Louis IX's reign is better in itself. He calls here, as elsewhere, for a return of the kings and kingdom to the devotion characteristic of Louis IX particularly during and after his first crusade (see, e.g., $\$ \$ 22,687$ ). A return to a simpler, less expensive style of dress in the royal courts would permit or coincide with a return to the sort of charitable works that St. Louis performed (see the listings at $\$ \$ 690-91,720-29,758)$. In this respect Joinville's concern for fashion is not simply a matter of appearance and custom: he is concerned, too, with moral and religious dimensions in attire.

Interpretations of the prime principle of style vary significantly when associated with different practices. On the face of it, the rule calls for moderation in dress-neither too showy nor too plain. Yet moderation does not serve as the sole measure for evaluating practice in the narrative, nor does St. Louis's attire in fact illustrate moderation. For example, at $\$ 667$ the description of his dress after returning from his first crusade implies a tendency towards austerity. This royal mode of attire poses a problem in his court, for it does not correspond to that of his courtiers. In a debate on fitting apparel at $\$ \$ 35-36$, Joinville and Robert de Sorbon assume the role of

(5) Joinville does not pronounce judgment on the hat with a white peacock plume or plumes that
Louis IX sometimes wore while hearing cases outdoors in Paris, $\$ 60$. 
fashion policemen ${ }^{6}$. In St. Louis's presence, Sorbon reproaches Joinville for wearing more luxurious clothing than the king. Then, Joinville justifies his own attire, which he received from his noble parents, and he reproaches Sorbon, the son of commoners («filz de vilain et de vilainne»), for dressing more richly than the king. In this public dispute several issues of appropriate dress come into play. The presumption is that in the royal court, no one should be more richly attired than the king. For reason of vestimentary codes, Joinville's accusation is graver than Sorbon's: not only does Sorbon don richer apparel than Louis IX, but his attire marks him as a parvenu who, as Joinville asserts, has abandoned his parents' dress, in other words, his social class. He argues, in effect, that one should not dress «above» his hereditary social class. Nevertheless, when Joinville says that he received his attire from his parents, it is unclear whether he means that in fact they gave him it (compare his mother's gift at $\$ 323$ ) or he is speaking figuratively about inherited privilege of the nobility. In any case, his interpretation of the principle of dress refers not to moderation but to a match between inherited class and attire.

In the comparison of Sorbon's, Joinville's, and Louis's dress at court, who is the practical model of fitting attire? Probably Joinville rather than the king, who is dressed less richly than the commoner or the noble. The narrative segment illustrates the king's wisdom: he agrees with Joinville's position, and he repeats the «neither too little nor too much» rule $(\$ 38)$. Yet the two courtiers' mutual accusations of overdressing could be understood to imply that the measure of comparison here, the king, errs on the side of too little.

The narrator's association of his parents and his attire in the debate suggests a relationship between clothing, particularly as a gift, and familial affection. Elsewhere he faults Louis IX for his seeming indifference towards wife and children, and on the other hand, he chides him for displaying too much grief at his mother's passing ( $\$ \mathbb{S}$ 594, 604). In the following, we shall first examine connections between clothing, its proximity to the body, and affection of various sorts. In one case, clothing offered as a gift is expressly intended as a formal sign of love. Then, we shall consider several instances wherein clothing and cloth point to real or imagined values related to the supernatural, political or social status, and moral or religious states including penitence, shame, and honor.

Embedded in the narrative of Joinville and Sorbon's debate on dress and St. Louis's final word on the matter, another development touching on clothing brings into play physical proximity and degrees of preferential affection. The king asks one of his sons and his son-in-law to sit near him on the ground, but they say they dare not place themselves so close to him; he then makes the same request of Joinville, who does not hesitate to obey. The narrator notes: «Et si fiz je si pres de li que ma robe touchoit a la seue» $(\$ 37)$. The king reproaches his son and son-in-law for their hesitation, and he places them after Joinville. The narrator opens his book by underlining the great affection that another of Louis IX's sons, Pierre d'Alençon, and the future Louis X's mother felt for him ( $\$ \mathbb{S} 2,4)$. It is possible to understand the garments' contact and the seating arrangement of the four parties as signs or confirmation of the king's affection for his dutiful companion surpassing even the natural love of father and son (cf. the seating according to the king's predilection at $\$ 430$ ).

In another instance an article of clothing is interpreted as a sign of preferential affection serving, further, as a symbol of political concord, or nonaggression, between two parties. There is no suggestion, however, of heartfelt affection between them. At 
$\$ 456$ the Old Man of the Mountain, chief of the Assassins, sends messengers with a shift, chemise, and a gold ring for Louis IX. He indicates through his envoys that just as the shift is worn closer to the body than any other article of clothing, so he wishes to hold Louis IX in his love closer than any other king. As for the ring, he says that it is a sign of their marriage or union ${ }^{7}$. The shift has no practical value here. Its value is emblematic as it points to a «loving» political association between the two leaders who have never met face-to-face. Earlier, the Old Man had his messengers threaten the king with assassination if he did not pay an annual tribute: one of them carried a shroud to give him if he refused $(\$ 451)$. Now his gifts, along with many precious items, serve as a formal sign that he withdraws his death threat, and they permit him to save face in doing so. The purport of the Old Man's gift of the shift is so arbitrary that it almost certainly would not be understood in the absence of his declaration of intention. In the case of another cross-cultural gift, Louis IX had in mind an attempt at religious conversion when he sent to a Mongol chieftain two Dominican emissaries and a chapel, a tent of scarlet cloth with embroidery depicting Christian mysteries; but the Mongols misinterpreted the gift as a form of tribute and a sign of the French king's submission $(\$ \$ 134,471,490)^{8}$.

If an article of clothing in contact with the body may indicate closeness and affection, whether symbolic or real, between two persons, then reports concerning an item of Joinville's attire suggest affection of a parent-child sort. In a first instance, when Saracens took Joinville prisoner in Egypt, they stripped him, sick and frightened, of his hauberk, and in an act of compassion, they gave him a coverlet. The rich fur-lined coverlet, which he then fashioned or had fashioned into a sort of tunic, was a gift from his mother $(\$ 323)$. He wore the makeshift garment throughout his captivity. It is perhaps significant that Joinville associates his mother with the coverlet, which became his protective clothing in a frightening situation where he was quite vulnerable. The coverlet serves in another case as an object of surrogate-parent-child transmission. At the beginning of his captivity Joinville took under his protection the natural son, about ten years old, of Ami of Montbéliard, to whom he was related ( $\mathbb{S}$ 332); after his release he gave the coverlet and some cloth to his ward (\$409). There is, moreover, a protective maternal gesture of a supernatural kind related to clothing at $\$ 121$ : in a nocturnal manifestation, the Virgin Mother covers the exposed chest of a sleeping monk, the abbot of Cheminon, with his cloak and, so, protects him from potentially harmful drafts. Her gesture may be understood as a sign of grace.

Heartfelt affection and a parental sort of protectiveness may only be inferred in the examples of the mother's and surrogate father's gifts of the coverlet. In another instance, however, Joinville relates a knight's comically irrational attempt to protect him from danger by clothing him. When their ship hits a sandbank near Cyprus, the sailors and passengers fear they will drown. Joinville, lightly dressed, leaves his quarters, and he is surprised when one of his knights covers his shoulders with a surcoat; he asks him what good it will do now that he faces drowning. The knight replies: «Par m'ame, sire, je avraie plus chier que nous feussions touz naiez que ce que une maladie vous preit de froit, dont vous eussiez la mort» (\$620). This exchange is one of many

(7) At $\$ 310$ an emir removes his turban and ring as a sign that he will honor a truce with the crusaders. Nevertheless, he breaks the truce shortly afterwards.

(8) Sarah-Grace Heller notes an example from La chanson de Jérusalem wherein a sultan gives a most richly «dressed» horse to a Frankish leader in order to win him as a convert to Islam-Fasbion in French Crusade Literature: Desiring Infidel Textiles, in D. G. KosLin and J. E. SNYDER, eds., Encountering Medieval Textiles and Dress: Objects, Texts, Images, New York, Palgrave Macmillan, 2002 («The New Middle Ages»), pp. 107-08. 
that Joinville recounts, it would seem, for the sake of humor. Nonetheless, it serves as evidence of the affection that his men felt for him-or so he would have readers believe in his self-promoting narrative, as he does, too, concerning some members of the royal family.

Frequently clothing or a style of dress in La vie de saint Louis indicates an interior disposition, a moral or religious state, personal identity, or the socio-military association of the wearer. For example, the different coats of arms, the subject of Joinville's fashion lesson to Philippe III, present heraldic devices, armoiries, that identify the person bearing them, his family, or troops bearing his arms. The identifying vestimentary sign is subject, however, to misreading. At $\$ \$ 261-62$ a Saracen chieftain exhorts his soldiers to attack the Christian army which he says has just lost its leader: he shows them the coat of arms of the recently slain Robert, count of Artois, Louis IX's brother, as proof of Louis's death. Apparently the Saracen chief mistook the count's arms, which display the fleur-de-lis, for the king's.

Attire signifying pilgrim or penitential status usually has its fixed official forms. The pilgrim's emblems that Joinville receives—a scarf and a staff-before setting out on Louis IX's first crusade are typical, but their bestowal by the abbot of Cheminon, to whom the Virgin showed her grace, gives them exceptional spiritual value in his eyes ( $\mathbb{S}$ 120-22). Moreover, upon leaving home, he dons penitential dress to visit nearby pilgrimage sites: with a woolen or hair shirt next to his skin, unshod he travels on foot (cf. $\$$ 632). His attire and actions indicate that he willingly humbles himself while enduring physical discomfort consistent with penitence or the fulfillment of a religious vow. This is one of the more emotional passages in his narrative: en route, for fear of losing heart he dares not look back at the fine castle where he leaves his two children. Penitential dress becomes the regretful sinner, lord, and father in the dramatic parting scene.

Joinville notes four instances of customs in Caesarea where rituals include clothing indicative of penitence, though not of a religious sort. First, the ritual of seeking pardon from a wronged party in one instance requires that the penitent, wearing only a shift and breeches, braies, kneel barefoot before the person-here, Joinville-whose forgiveness he solicits $(\$ 510)$. The attire resembles in part the penitential dress prescribed in the case of a sinful knight, a fornicator seized in a brothel: in order to beg Louis IX's pardon and remain in his army, he must don only a shift while a prostitute holding a rope tied to his genitals leads him through the assembled troops $(\$ 505)$. The knight chose, however, to leave the army and forfeit his horse and armor-perhaps he found the custom and attire more indicative of disgrace than penitence. Joinville observed two other penitential rituals involving members of militant orders. Among the Hospitalers, a penitent brother must eat sitting on his cloak until the offended party or the order's master asks him to rise, that is, forgives him ( $\mathbb{S} \mathbb{S}$ 507-08). In the case of the master of the Templars who seeks St. Louis's forgiveness, he kneels before the king and extends one edge of his cloak to him as a sign that he is penitent (\$\$ 511-14). In the last two examples, St. Louis forgives the master of the Templars but severely punishes the order's marshal, and the master of the Hospitalers withholds his pardon until Joinville, the offended party, forces his hand by joining the penitents on the ground. Thus, in two of the four cases that he relates, Joinville appears as a paragon of clemency.

Gifts in La vie de saint Louis frequently include clothing or cloth. Their valuation as offerings varies significantly. We have already mentioned the Old Man of the Mountain's gift of a shift signifying love or, practically, a formal offer of nonaggression. St. Louis responds by sending him scarlet cloth along with jewels and gold and silver articles $(\$ 458)$. The king's gifts signify his acceptance of the Old Man's love offering. La vie de saint Louis opens and closes with a potential exchange of gifts: 
Joinville presents his book to the future Louis X ( $\mathbb{S} 18)$, and he asks him for a gift of relics $(\$ 767)$. We shall return to this example of reciprocal gift-giving shortly. During his captivity in Egypt, Louis IX received rich garments, of fur-lined black satin with gold buttons, as a gift from his captor, the sultan $(\$ 403)$. The gift probably should be understood as signs of the giver's largess and of hospitality that the captor offers his captive?. We might compare the Egyptians offering food rather insistently to Christian captives upon their release, for, as the former said, «ce seroit honte aus amiraus se vous partiés de nos prisons a jeun» $(\$ 375)$.

In another development dealing with cloth that changes hands, Joinville points to important financial and honorific values of Eastern textiles for Christian militants in Syria. He remarks at $\$ 527$ that his relation Gautier IV, count of Brienne and Jaffa, financed his endeavors there in large part through plunder, and the booty from one particularly profitable raid on a Muslim caravan included much silk and cloth of gold. He casts neither blame nor shame on this robber-baron activity-he notes that the count's victims were infidels ${ }^{10}$. His account illustrates, on the contrary, the pious count's lordly virtue of largess, since he gave the booty to his knights and kept nothing for himself. Readers may understand, nevertheless, that the precious cloth in fact serves as remuneration for the knights in his service. In a narrative dealing frequently and in great detail with the practical question of how Christian leaders engage and remunerate their troops in the East-Joinville is often involved in such matters- the value of plunder in maintaining a Christian army in this instance is most significant. It is perhaps ironic, then, that in order to pay a great honor to a Muslim knight, the sultan of La Chamelle, whom Christian barons and the patriarch of Jerusalem hope to enlist in their army, they cover the ground upon which he passes in Acre with (plundered?) cloth of gold and silks ( $\$ 529)$.

Shame is associated with a gift of cloth in another example. When Joinville meets in Cyprus Marie, the empress of Constantinople, she possesses only the clothes on her back, for a strong wind drove her boat, along with her baggage, to Acre. After Joinville sends her cloth and furs for making a dress, Philippe de Nanteuil complains to Louis IX that because Joinville failed to inform him and the other lords of her need, his gift has shamed them greatly $(\$ \$ 137-38)$. The narrator relates this anecdote without comment, without defending himself - after all, why protest when the honor falls to him alone? He perhaps thought the complaint, a backhanded manner of conferring honor on himself, to be comic or witty and, therefore, worth repeating.

Today's readers may not find to be amusing many of the anecdotes that Joinville relates in order to entertain. A case in point: when his men ask him what he intends to do with a hundred pieces of cloth the king had him purchase as a present for the Franciscans, he answers facetiously that maybe he will steal them for his own profit ( $\mathbb{S}$ 599). Of course, his reply would not be even slightly humorous were he a known thief of cloth or apparel like his valet Guillemin whom he dismisses (\$417).

Nonetheless, a second anecdote about Joinville's gift of cloth to another royal lady is quite amusing due to her misunderstanding. After he transmits to St. Louis some relics, a gift from the prince of Antioch, and the fabric just mentioned, he sends four pieces of cloth wrapped in white linen to Marguerite of Provence, the queen, who, believing them to be relics, kneels before them. She laughs when Joinville's mes-

(9) The sultan's gift to the king might correspond to the honorific garments that caliphs and other Islamic leaders distributed-see HELLER, Fashion, pp. 109-11.

(10) Louis IX did not tolerate preying on
Christians by robber barons in France, $₫ 124$. On clothing thieves in the East and Paris, see $\$ \$ 116$, 417. Booty of silks and gold cloth is common in French crusade poetry-Heller, Fashion, pp. 103 and 106. 
senger apprises her of her error $(\$ 601)$. Her confusion is comical, but her mistake about the nature, or supernature, of the cloth calls for an explanation. It may be that she had been informed of Joinville's delivery of the prince's present to her husband and that she presumed his subsequent transmission to her to include other relics from the prince. At any rate, the association of cloth and relics is rather common. A holy person's contact was believed to impart supernatural properties to clothing-e.g., Christ's garments at Matthew 9.20 and 14.36 and handkerchiefs or sashes in Paul's case at Acts 19.12 are said to possess miraculous healing powers. Closer to Joinville's time, the first of the hundred novelle in Giovanni Boccaccio's Decameron, about Ser Cepparello, a sinner (mis)taken for a saint, concludes with a description of believers who tear from his corpse the clothes which, it appears, they considered to be venerable relics: «...e tutti i panni gli furono indosso stracciati, tenendosi beato chi pure un poco di quegli potesse avere...e a mano a mano il dì seguente vi cominiciarono le genti a andare et a accender lumi e a adorarlo $\gg^{11}$. In light of the attribution, whether comical or serious, of supernatural virtues to garments, one might ask a question about St. Louis's relics, objects of devotion, that Joinville requests of the future Louis $\mathrm{X}$ in the conclusion to his book $(\$ 767)$ : would he have been satisfied with an article of the saint's clothing rather than his bones, bones that he jokingly declined to venerate during the king's lifetime (see $\$ 566$ )?

The representation of St. Louis's bottomless breeches suggests, too, the association of clothing with sanctity. Joinville maintains in the introduction that the king deserved to be included among the martyrs of the faith for reason of the great suffering ${ }^{12}$ he endured patiently during his crusades and, particularly, since he died having taken the cross $(\$ 5$; cf. Joinville's comments on crusading and martyrdom at $\$ \$ 393,538)$. He lists four of St. Louis's deeds during the first crusade that illustrate his courage in exposing his person to death. The second involves his refusal, after the army's defeat at Mansûra, to follow his advisors' recommendation to flee by ship so as to avoid capture. He is loath to abandon his soldiers, many of whom are sick or wounded. Joinville notes that the advisors made their recommendation especially because of the king's physical state then: he was suffering from dysentery as well as two other debilitating illnesses, one of which caused him to lose consciousness several times. The diarrhea was so severe that at night his attendants had to cut out the bottom of his breeches $(\$ 10)$. He remarks later that the operation was performed each time the king needed to use the privy $(\$ 306)$. The narrator insists elsewhere on his own obligation as a knight and lord not to abandon those under his command overseas, for to do so would bring disgrace upon him $(\mathbb{4} 421)$. Surely he appreciated in Louis IX this noble virtue-the lord who, for the sake of his soldiers, does not flee in the face of danger or even death. Nonetheless, the implicit association of the chivalric or feudal virtue, through the king's bodily affliction, with Christian martyrdom is noteworthy. Taken ill with diarrhea again on his second crusade, he dies in bed in what Joinville

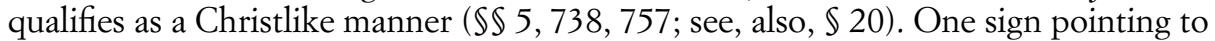
the sanctifying value of his suffering and sacrifice is the unusual cut of his breeches.

In conclusion, garments and cloth in La vie de saint Louis reveal, if read properly, inner meaning or in the case just mentioned, the higher man in spiritual terms. They require attention to details of style in order to assess inner significance. For example, while reporting on the quality of fabrics and materials in St. Louis's attire at

(11) Decameron, vol. 4 of Tutte le opere di Giovanni Boccaccio, ed. V. BrancA, Milano, Arnoldo Mondadori, 1976 , p. 46.

(12) For a comparison of depictions of the king's suffering in Joinville, Guillaume de Saint-Pathus's
Vie de saint Louis, and other contemporary texts, see J. LE GofF, Un roi souffrant: Saint Louis, in La souffrance au Moyen Âge (France, XIIe-XVe s.), Varsovie, Éditions de l'Université de Varsovie, 1988 («Cahiers de Varsovie, 14»), pp. 51-71. 
$\$ 667$, Joinville notes a correspondence between their simplicity and sobriety and the king's simple tastes in cuisine and sobriety in drink. These elements of style after his first crusade show a change from the young king's rich attire at Saumur; they show, too, an inner change, his markedly greater religious devotion from around the time of that crusade.

On a superficial level, dress in the royal and aristocratic milieus that Joinville frequented is mostly a matter of taste, style, and custom, but he and several of the actors in his narrative assign or suggest ascribing ethical, social, affective, and religious values - one might say added-on values - to clothing and cloth. The covering is meaningful to the extent that it reveals something of value about what it covers. Dress solely for the sake of dressing, for an appreciation of the covering itself, does not play a predominant part in La vie de saint Louis. As mentioned earlier, Joinville endorses the mature St. Louis's preferred attire a generation or two after the king's demise without any apparent concern that the style is long outmoded. The narrator's and others' valuation of attire and cloth involves their recognition or discovery of a proper fit between outside and inside. The correspondence is sometimes social, as with the question of class and appropriate apparel in the debate with Robert de Sorbon. The question of attire, like that of class, as something inherited from one's parents also comes up when Joinville exhorts Philippe III to adopt his father's less than lavish style of coats of arms. The parent-child association with regard to clothing is suggestive of affection and obedience as duties of offspring. Joinville argues at $\$ 761$ that St. Louis's successors bring honor to their lineage when they follow his model, and they shame themselves and their family when they do not.

In his fashion lesson to Philippe III, Joinville moralizes the relationship between style of dress and Christian works. The question of style here is part of a long tradition denouncing luxury and moral corruption. Moralization in the sense of performing an exegetical lectio is evident in the Old Man of the Mountain's gift to St. Louis. There, as with the previously cited instance, the correspondence between attire and inner meaning is fairly strained and arbitrary. In both cases, however, the interpretations exemplify common practices with respect to integumentum in the Middle Ages: the explicative sermon and textual exegesis. The association of supernatural qualities and attire or cloth in the narrative is consistent, too, with reading practices then. Regarding the report wherein the Virgin touches a monk's robe, Jean-Claude Faucon remarks that it conforms so perfectly to the typology of the popular miracles of Our Lady that the narrator does not need to provide proof of its validity ${ }^{13}$. Further, the symbolic value that a priest assigns to St. Louis's clothing in Joinville's prophetic dream at $\mathbb{S} 731-32$ conforms to oneiric interpretive practices found, for example, in the popular thirteenth-century Lancelot-Grail prose romances, which abound in dreams and elaborate explanations ${ }^{14}$. One may assume that for the most part, Joinville's aristocratic audience was familiar with dreams and their elucidation in fictional works claiming to tell the truth. The narrator's and his actors' explications related to clothing and fabric show them to be relatively sophisticated readers.

(13) Rumeur et oui-dire chez Joinville, «Littératures», XXXVII, fall 1997, p. 13. The narrator was perhaps less confident than J.-C. Faucon about the report's generic conformity as self-sufficient proof of validity, for he employs several authenticating techniques, along with the use of direct discourse reaffirming his aural-witness position, to persuade readers that his thirdhand account warrants belief.
Among these is the identification four times of actors in the brief relation as preudommes, men of excellent moral qualities, i.e., worthy of belief.

(14) See, e.g., my Dream-Engendering Dreams in the Old French "Lancelot", «Mediævalia», XXII, 2, 1999, pp. 343-58, and Dreams at Conception in the French Lancelot-Grail Romances, «Quidditas», XXI, 2000, pp. 45-57. 
Although a fervent admirer of St. Louis, Joinville does not submit unquestioningly to his judgment regarding a fit between attire and the wearer. He underlines his own independent judgment and trustworthiness in matters of style and value ${ }^{15}$. In an anecdote meant, according to the narrator, to illustrate Louis IX's humility, he relates that the king accused him before the papal legate of a misdeed in preventing a cleric, a man of the cloth, from approaching him at mass. He suspected the man was an Assassin in disguise: his physical appearance-he was large, dark, and hirsute - did not match his clerical attire. For the king, however, the habit makes the monk: he believed the man to be what his costume indicated. After the legate decided in Joinville's favor, the king, unyielding, continued to defend his position (\$\$ 589-90). Who was right? The narrator permits readers to view the suit as a win-win situation, to appreciate his prudent judgment approved by the legate and the king's saintlike character. While Joinville usually defers to his king in questions of Catholic faith and government, he trusts solely his own judgment in evaluating dress and the man.

REGINALD HYATTE

(15) Joinville often points out that Louis IX sought advice but made decisions independ- ently-e.g., $\$ 669$ - and he appears to value this trait in his king. 